Izvorni znanstveni rad

DOI: $10.17234 /$ Croatica.41.9

UDK: 821.163.42-97.09:398.5

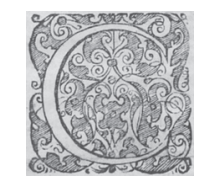

\title{
KAD SE NEBO OTVORI: BIBLIJSKE I PARABIBLIJSKE PRIČE U USMENIM PREDAJAMA
}

\author{
Ljiljana Marks \\ Institut za etnologiju i folkloristiku \\ marks@ief.hr
}

\begin{abstract}
Apokrifi u srednjovjekovnoj hrvatskoj književnosti nisu jedinstvena žanrovska kategorija i mogu se promatrati kao nadžanrovska skupina tekstova koji pripovijedaju o biblijskim osobama i njihovim zgodama ili djelima kojih nema u biblijskome kanonu. Premda su to fiktivna zabavna djela, zgode su uvijek ispripovijedane kao nefikcionalne, u čvrstom odnosu prema biblijskim sadržajima, kršćanskoj pouci i etičkoj poruci. Bili su namijenjeni čitanju naglas i slušanju pa ta otvorena forma omogućuje osobni stil, posuđivanje i kombiniranje motiva, slobodno shvaćanje kronologije ispripovijedanih događaja, djelovanje na emocije recipijenata ganućem i zabavom, ali i ritam pripovijedanja kao u usmenoj književnosti. Na temelju korpusa usmenih predaja i legendi (iz starijih i novijih zapisa) pokazuje se što se događa kad "sveti tekst" potpuno prijeđe u usmenost: tekstovi se preoblikuju, nepojmljivo se objašnjava bliskim, Božje nadomješta ljudskim, no ono što u tom procesu folkloriziranja nastaje jest više ili manje uspješna mješavina komičnog i ozbiljnog, vesela, opuštajuća Biblija, koja služi i smijehu i pouci, a pritom oblikuje cjelinu. Slabljenjem prvobitne pouke jačaju fantastični bajkovni elementi, izvorna se biblijska priča dopunjava apokrifima, pri čemu se upleću legendarno, šaljivo i bajkovito. Najbrojniji su tekstovi kozmogonijskih i etioloških predaja koji najjasnije izgrađuju smisleni most između onoga nekoć i ovoga sada, progovaraju lokalnim pripovjedačevim jezikom, imenuju i objašnjavaju svijet podarujući mu dodatno značenje.

Interpretacijom primjera tekstova o postanku svijeta, stvaranju ljudi, navještenja i rođenja Isusova, bijega Svete obitelji te, posljedično, o čudima oko Božića, pokazuje se da pripovjedački korpus koji pritom nastaje nije samo slučajna mješavina, a pogotovo ne ne-
\end{abstract}


razmrsivo klupko tekstova heterogena podrijetla i različite starosti, već više ili manje uspješna mješavina komičnog i ozbiljnog. Sve su te priče, zajedno s brojnima ostalima koje bismo mogli uvrstiti u neku hrvatsku Bibliju pauperum, dojmljiv dokument o tome kako je dvije tisuće godina kršćanstva i kršćanskoga nauka shvatio, interpretirao, sačuvao i prenosio narod.

Ključne riječi: Biblija, parabiblijske priče, predaja, apokrifi, usmena književnost, Hrvatska

Apokrifi u srednjovjekovnoj hrvatskoj književnosti nisu jedinstvena žanrovska kategorija i mogu se promatrati kao nadžanrovska skupina tekstova koji pripovijedaju o biblijskim osobama i njihovim zgodama ili djelima kojih nema u biblijskome kanonu. Premda su to fiktivna, katkad zabavna djela, zgode su uvijek ispripovijedane kao nefikcionalne, u čvrstom odnosu prema biblijskim sadržajima, istinite prema svojem moralnom smislu, kršćanskoj pouci i etičkoj poruci. Ti su tekstovi jednako utemeljeni u povijesnom događaju, čija je konfliktna struktura binarna, označena kontradiktornošću, zaoštravanjem kao i ulaskom u imanentno i transcedentno (Fališevac 1980; Ecker 1996: 860; Dürrigl 2013: 11-53, 57-71).

Nema cjelovitog tekstovnog korpusa apokrifa, već ih najčešće pratimo u fragmentima u širokom rasponu žanrova ponajviše u glagoljaškoj sastavnici hrvatske književnosti od 13. do 17. stoljeća: u eshatološkim vizijama, apokaliptičnim evanđeljima, glagoljaškim crkvenim govorima (slovu, primjerice Slovo o blagovijesti), u mirakulima/legendama, prenjima, pripovijetkama, egzemplima. Intenzivno su živjeli kroz cijeli europski srednji vijek u zbornicima (Petrisovu, Žgombićevu, Vinodolskom) - često kao kompilacije posvećene čudesima što su pratila Isusovo rođenje (i uz to vezan bijeg Svete obitelji u Egipat, pokolj nevine dječice, povratak u Nazaret; govore i o Ivanu Krstitelju, Pilatu, Herodu i rimskim carevima iz doba Kristova djetinjstva) - te kao apokrifni tekstovi uz propovijedi o Kristovu rođenju i djetinjstvu u glagoljskim zbirkama pučkih pripovijesti koje su relativno kasno datirane kao ekžempli, egzempli, prilike (Hercigonja 2010: 52-54). Pisani spisi su k nama dolazili od bizantskih, orijentalnih do latinskih (talijanskih, njemačkih) te čeških izvora i tu se prevodili, adaptirali i prepisivali.

Gotovo su istovjetni bili i putovi širenja motiva i sižea u usmenim tradicijama te gotovo invarijantnim inačicama i u drugim europskim zemljama - od Sicilije i Malte do Rusije; posvuda gdje su se udomaćili obogatili su se detaljima i elementima lokalne kulture i usmene tradicije (Dähnhardt 1983: IV-VI). Od svojega su početka bili namijenjeni čitanju naglas i slušanju pa je tomu prilagođena i otvorena forma koja omogućuje osobni 
stil, posuđivanje i kombiniranje motiva, slobodno shvaćanje kronologije ispripovijedanih događaja, djelovanje na emocije recipijenata ganućem i zabavom, ali i ritam pripovijedanja, ponavljanja. Zbog svega toga, kao i težnje prema istinitosti, zbiljnosti i pouci, potpuno odgovaraju poetici usmeno prenošenih tekstova, ponajprije legendarnih priča i predaja, te nije čudno što su se apokrifne teme ugodno, udobno, komotno i trajno uselile u usmenu književnost.

Teme srednjovjekovnih apokrifa: starozavjetne priče o stvaranju, potopu i Noinoj lađi, nagovještaji kraja svijeta, život Adama i Eve, dijelovi priče o Josipu kojega su braća prodala, Marijin život, navještenje, Isusovo rođenje, bijeg u Egipat i Isusovo djetinjstvo, mirakuli i Marijina čudesa, kasniji život apostola, ponajprije Petra gotovo uvijek uz Isusa u šaljivim legendarnim pričama, potom mučenika (Sv. Katarine, Sv. Lucije) podjednako su tematizirane u objema tradicijama, pisanoj i usmenoj.

Te su priče horizontalno od samih početaka prenosila nomadska plemena u svojim lutanjima prema svetištima, hodočasnici, putujući pripovjedači. Prenosile su se i vertikalno u vremenu sve do naših dana, jednostavnim ponavljanjem i prepričavanjem. Oni koji su ih slušali nisu uvijek bili dovoljno obrazovani da bi razumjeli likove i događaje pa se tradiranjem pojednostavljuju, postaju priprostije, naivnije, ali i šarmantnije. Ponajprije se nepojmljivo objašnjava bliskim, Božje nadomješta ljudskim, no ono što u tom procesu folkloriziranja nastaje nije samo slučajna mješavina, a pogotovo ne nerazmrsivo klupko tekstova heterogena podrijetla i različite starosti, već više ili manje uspješna mješavina komičnog i ozbiljnog, vesela, opuštajuća Biblija, koja služi i smijehu i pouci, a pritom oblikuje cjelinu. Slabljenjem prvobitne pouke jačaju fantastični bajkovni elementi ${ }^{1}$ ili pak elementi šaljivih priča, koji preuzimaju fabulu i atmosferu te ti tekstovi prelaze u drugi žanr, najčešće u šaljive priče. ${ }^{2}$

1 Primjerice motiv o Djevojci bez ruku jedan je od najoptjecajnijih europskih motiva o progonjenoj ženi koju čudom i milosrđem spašava Djevica Marija. Nalazimo tiskanu verziju u senjskom glagoljskom izdanju (Mirakuli slavne Deve Marije) još 1507. ili 1508. godine. Tradiranjem gubi legendarni značaj, postaje bajkom, ali svojom popularnošću utječe na preuzimanje srodnih pripovijedaka iz drugih izvora ili svoje motive $\mathrm{i}$ epizode ugrađuje u druge pripovijetke. U Hrvatskoj su zapisane brojne inačice motiva koje pokazuju da se pripovjedački postupak potpuno promijenio u duhu folklornoga kazivanja (više u Bošković-Stulli 1987: 102-113; Kekez 1989: 86-89).

2 Egzempli koje je godine 1917. i 1918. iz rukopisnih vrela negdašnjih popova glagoljaša pod naslovom "Prilike" iz stare hrvatske glagolske knjige objavio R. Strohal (Zbornik za narodni život i običaje južnih Slavena 21, 239-272; 22, 257-288; 23, 64-124) bili su glavni izvor za 
U sadržaje ležerno uvijek upisuju i aktualno pripovjedačko doba, svoju interpretaciju biblijskoga događaja, vrijednosti i estetiku (Gunkel 1901: 88-122). Tim su postupcima omogućile svim pripovjedačima i publici diljem europskih prostora da angažirano i stvaralački svaki put iznova kreiraju i istodobno komemoriraju biblijsku priču. U dugotrajnome procesu prepleli su se i stopili utjecaji svih onodobnih kultura (babilonske, egipatske, grčke); židovska tradicija preuzima protagoniste i zauvijek ih kontekstualizira u svoj zemljopisni prostor, koji poslije postaje i starozavjetni i novozavjetni krajolik u gotovo svim kršćanskim tradicijama. Pritom je potpuno nevažno što se poslije proširene i prepričavane lokalne inačice ne događaju uvijek u tom kanonski prepoznatljivom biblijskom krajoliku, nego na prostorima koji su recipijentima vizualno bliski, domaći - pa i kad su izrijekom spomenuti Betlehem, Galileja, Nazaret - a životinje i biljke u njima su gotovo iz kućnoga dvorišta. Biblijska priča postaje time i osobna, i lokalna, i priča trenutka, i svevremena.

Najbrojniji su tekstovi kozmogonijskih i etioloških predaja, dakle tekstovi koji objašnjavaju kako i zašto je nešto postalo - nebeska tijela i pojave, biljke, životinje - zašto je upravo takvo kakvo je i otkud im ime. To nije čudno jer je tumačenje odgovora na pitanje o podrijetlu svih stvari, ljudi i životinja, na cijelome svijetu elementarni pripovjedački poticaj. ${ }^{3}$ Stoga je očekivano da upravo etiologije, oblikovane kao manje ili veće narativno strukturirane cjeline, u usmenim tekstovima najčešće i najjasnije izgrađuju smisleni most između onoga nekoć i ovoga sada. Služeći se prošlošću, one, zapravo, uvijek prikazuju sadašnjost. Pritom sadašnjosti daju dostojanstvo, smisao i cilj jer je uvijek čvrsto usidruju u prošlost, ali samo onako kako je one vide, tumače i poentiraju. U tome s podjednako važnim ulogama sudjeluju i mitske i povijesne sastavnice.

Svijet hrvatskih kozmogonijskih predaja govori nam o tome kako su postale buhe i uši, krtica, pčela, zašto koza ima kratak rep, zašto slavuj noću pjeva, zašto čovjek ima jabučicu na grlu, kako su postale dlake na

književnu valorizaciju toga korpusa, ali i za propitivanje usmenoknjiževne sastavnice jer se u njima prepoznavao odjek trajnih fabula, motiva i tipova priča, u ovome kontekstu ponajprije s naglašenom moralnom poukom (Maja Bošković-Stulli, Josip Kekez, Divna Zečević). Dodatni je istraživački impuls dolazio iz aktualnih terenskih istraživanja i zapisa sličnih motiva.

3 Etimološku igru imenima, odnosno imena koja govore, nalazimo od antičke preko srednjovjekovne, renesansne, barokne do suvremene književnosti (Curtius 1971: 497-501). Pučka etimologija u usmenim tekstovima samo slijedi tu igru značenjima imena. 
čovjeku, zašto zemlja iz sebe izbacuje zle i još o mnogo čemu. Sve progovaraju jezikom svojega zavičaja, imenujući i objašnjavajući svijet koji ih okružuje, podarujući mu dodatno značenje. Ta su tumačenja, koliko god bila naivna, razumljiva i logična u njihovu svijetu. Vrijeme kada se to dogodilo nije određeno, ali jednako može biti jučer kao što može biti u neko pradavno doba kad je nastajao svijet.

Tako ćemo saznati kako su nekoć bila dva ili čak tri sunca, ali ih je popila zmija. Zemlju je jednom spasila gušterica, pa zato uvijek stoji na suncu (Krmpotić 1913, 18/1: 190-191); drugi ju je pak put spasila lastavica, u prvo doba prokleta ptica iz zemlje Indije, ali

poslije je postala blagosovljena jer je očuvala četvrti dio sunca kad ga je hotila zmija popiti, a ona mu nekako četvrti tal sakrila pod krila. I kad ga je donijela Bogu - po sto mu put slava! - onda joj je on rekao da će odsele biti svakome mila i draga, kao što ju je dosele svak mrzio i proganjao, i da će svoja gnijezda viti pod ljudskijem strehama kao nikakva ptica do sada, a da je za to ljudi neće progoniti, nego da će im biti kao kutnje čeljade (Zovko 1898/3: 45).

Vele, da je nebo bilo prije ovako dole namah nad zemljom: mogao si ga rukom dohvatiti. A nekakva baba benasta metala kruh u peć pa shvatila nebo loparom, i ono se diglo gore (Krmpotić, 1913, 18/1:190-191).

Grmljavina nastaje u Kotarima stoga, "pričaju otočani [jer] svijet počiva na ogromnim rogovim još ogromnijeg vola, koji kad ogladne i prigiblje glavu da pase, svijet mu ispuzava sa rogova, a to da prouzrokuje grmljavinu. Kotarani vjeruju da zemlja gori kada grmi” (Zorić 1896/1: 259).

Postanak Mliječne staze spada među najraširenije i još uvijek prepričavane kozmogonijske predaje: najčešće je znana kao Kumovska slama jer je, ne znam tko to ne zna, kum kumu krao slamu i to su ti tragovi na nebu. Ime je samorazumljivo, ali katkad je na kraju opća moralna pouka "onako je Bog učinio i po nebu i tim nam je dokazao, da se nikakva tajna zatajiti ne može" (Bošković-Stulli 1993: 243).

Zapis iz Slavonije o dvama kumovima, siromašnom i bogatom, narativno je razvijena predaja, udomaćena kao aktualan, suvremen događaj, kao da se u pripovjedačevoj percepciji i događaja i vremena netom dogodio: siromašni kum ima svinje i kravicu, ali nema slame da ih hrani, pa tu pripovjedač zapravo nalazi opravdanje za krađu: "I nije ovaj imo ni slame, ni ništ. A imo je tak kravicu i svinja, i trebala mu je slama, a ni imo zemlje. I ovaj kum je uvek njemu davo slamu." Siromahu to pak nije dovoljno te krade noću slamu bogatoga "pa nosi slamu i tako kako je krô slamu, nosio, 
vuko, tako se na nebu pozna i sada štrafa. Samo pazite kad mesec jako sjaje na nebu kako je štrafa! Slama se prosipala kako je kum sa njom išô (Marks 1974: br. 45). Izravno obraćanje istraživaču: "Samo pazite kad mesec jako sjaje na nebu kako je štrafa!" jest uobičajen stilski postupak pripovjedača predaja u nakani da uputi na potencijalnu zbiljnost događaja.

Uza slamu i sv. Petra vezan je isto tako postanak tog nebeskog puta, što samo upućuje na široku lepezu mogućih protagonista te zgode. Mliječna staza nastala je i kad je "sv. Petar, bježeći izpred Žudija, prosipao putem slamu da mu se izgubi trag po zemlji da im ne upade u ruke, a taj put slamnati da se sad zrcali na nebu" (Zorić 1896/1: 259). Potom kad je sv. Petar obećao bratu Andriji da neće biti kiše, a kad je sve urodilo i bilo obilja slame, Andrija ju je prosipao, "a trag joj se sad vidi po nebesim" (isto).

Žanrovska zamućenost i tu je ostavila traga. Cjelovite tekstove nalazimo tek od 19. st. ponajprije u Zborniku za narodni život i običaje južnih Slavena (ZNŽO) i potom u objavljenim zbirkama, ali i u terenskim zapisima u dokumentaciji Instituta za etnologiju i folkloristiku (ponajviše N. Bonifačića Rožina i O. Delorka, manje M. Bošković-Stulli, D. Zečević te Lj. Marks), do danas bez jasnog žanrovskog razgraničenja. Obuhvaćaju legende, legendarne priče, šaljive priče (švank) i ponajviše etiološke, kozmogonijske i mitske predaje. ${ }^{4}$ Suvremene su klasifikacije naravno drukčije, ali su isto tako nejasne jer ti tekstovi plutaju i u rukopisnim i u objavljenim zbirkama pripovijedaka od legendarnih bajki, šaljivih i svagdanjskih pripovijedaka, švanka, legendi, legendarnih priča do etioloških, kozmogonijskih, objasnidbenih i mitskih predaja. Ne smijemo zanemariti da su neki od tih sadržaja ostvareni i u stihu u pučkim molitvicama, katkad s podjednakim prodorom pretkršćanskih sastavnica. Dramska uprizorenja potonula su danas uglavnom u ophodne običaje s oskudnim tekstovnim dijelom (Betlemari, Zvjezdari, Adam i Eva). Pitanje žanra tih tekstova nije tako jednostavno ni u pisanoj

4 Primjerice, u Radićevoj Osnovi, koja je prva klasifikacija te građe, predaje s apokrifnim temama nalaze se u trima poglavljima $(10,11$. i 12.) i u 14 različitih točaka, nejasno određenih sadržajnih tema prema kojima bi ih valjalo razvrstati. Radićeva klasifikacija nije važna samo zbog pronalaženja tekstova nego ponajprije zbog onodobnog shvaćanja, odnosno neshvaćanja različitosti proznih žanrova u zapisima koji su dolazili. Slijeđen je tradicijski obrazac da je narodna duša u poeziji pa se i proza, kao dio duše, nalazi u poglavlju pod nazivom Poezija. "Srce može biti veselo, srce može uživati, a samo je duša srećna. Kakav je sebi drugi taj svijet stvorila narodna duša, to se vidi iz narodne poezije i narodnoga vjerovanja. Među poezijom i vjerovanjem (mitologijom) nema prave granice. Nama i nije ovdje do toga, to je i opet posao posebnoga izučavanja" (Radić 1929/2: 64). 
književnosti, gdje su te teme raspršene unutar više žanrova: apokrifa, prenja, legendi, pripovijedaka, poezije - i to samo za sebe nije problematično jer je u središtu tema, a ne vrsta u kojoj se ostvaruje.

Većina tema koje su u središtu parabiblijskih usmenih priča podudarna je u svojem najširem smislu s biblijskim kanonom, primjerice postankom ljudi, životinja i sl., ali biblijske priče o postanku prije su u tim neposredno prenošenim tekstovima zrcalni fragmenti te velike priče nego početni pripovjedački oblik. I inače su mitovi o stvaranju u brojnim kulturama pomoćno sredstvo za spekulacije i prosudbe. U zapadnom su kulturnom i znanstvenom kontekstu, pa i u nas, od 19. st. bili uglavnom dijelom filologije, katkad otvoreni mitologiziranju i propitivanju naknadnog života (germanskih, islandskih mitova itd.) u kršćanskome kontekstu (N. Nodilo), a katkad striktnim filološkim zaključcima (V. Jagić). Za razliku od starijih istraživanja, koja su i sama poticala "mitskost" tih priča i koncentrirala se na prikupljanje i usporedbu što više tekstovnih inačica pojedinog motiva u različitih naroda, novija istraživanja propituju njihovu društvenu i kulturnu funkciju te mjesto u životu i tradiciji pojedinih kultura.

Otvorila su ta istraživanja nove niše: poganski, pretkršćanski imaginarij iz pučke kulture uklizao je kao očuđenje u kršćanske tekstove, ispunio ih maštovitim i nestvarnim, a životu bliskim detaljima uglavnom etioloških predaja i smatram da su upravo zbog toga opstali do danas. U kristijaniziranome društvu nemaju više status ni apokrifa ni svete priče: dio su manje ili više živoga pripovjedačkoga repertoara (Frenschkowski 2005: 173-174). Čvrsta povezanost tih skupina tekstova nije u njihovoj formalnoj, pobožnoj funkciji i sadržajnim motivima koji se odnose na nadnaravno, pobožno i sveto, nego u stilskoj srodnosti te u zajedničkom dijeljenju zaliha jezičnih šifri i simbola. Njihova je referencija ostala do danas u filologiji, etnologiji i folkloristici uglavnom kao tekstova koji vjerski naivno objašnjavaju svete stvari s težištem na motivskim, jezičnim i semantičkim promjenama koje su doživjeli od srednjovjekovlja do postindustrijskoga doba.

U nas je taj tematski korpus u okviru usmene književnosti ostao rubno istražen, uglavnom kao dio nerazmrsivoga tkanja usmene i srednjovjekovne (uglavnom glagoljaške) pisane tradicije u povijestima hrvatske usmene književnosti s različitim žanrovskim naglascima sve do naših dana (egzempli, prilike, legende, legendarne priče, šaljive priče, parodije, molitvice). U teorijskim radovima o tim tekstovima kao o folklorističkom žanru najčešće su razmatrane legende, svetačke biografije i čudesa, mučeništva, premda se većina tih teorijskih eksplikacija može prenijeti i na ostale žanrove u čijem 
je tematskom fokusu biblijska priča. U konstruktivističkom se pristupu stoga nastoje iznova definirati granice i djelovanje žanra kao dinamičnog tekstovnog žanra s mekim prijelazima prema sličnim motivima u srodnim žanrovima (miješani oblici, legendarne priče, etiološke legende), sa sviješću o njegovu najrazličitijem povijesnom, književnom i kulturološkom tretmanu. Poticaj se još uvijek pronalazi u Jollesa pa se s jedne strane postavljaju hagiografije svetaca kao uzornih "etičkih virtuoza", a s druge kao "čudesnih pomoćnika". Fabula se u zapisu usmenoga teksta legende odmiče od reprezentativne svečeve biografije i prilagođava logički narativno zatvorenoj fabuli koju zahtijevaju predaja, bajka, legendarna priča, švank (Ecker 1996: 859). Pobožna intencija legende ulijeva se u općenitu dimenziju značenja priče (Relevanzaspekt) i nastoji svojim recipijentima tumačiti kako se nositi s postojanjem svetih stvari punih značenja. Legenda teži konstrukciji (prividne) stvarnosti. Ona ima i ideološke, sociološke i društvenopsihološke dosege jer održava jasno vidljivim određen dogmatski sustav, snaži i podupire čovjeka koji se pita kako se nositi s vlastitim postojanjem, kako smisleno znati razlikovati, poistovjetiti se s nečim, prihvatiti (Ecker 1996: 860).

Nemoguće je, a i nepotrebno, utvrditi dijakronijske i sinkronijske putove usmenoga i pisanoga u srednjovjekovnim tekstovima i u usmenim zapisima. Među samostanskim zidovima živjeli su ljudi koji su uglavnom dolazili iz naših siromašnih sredina, slabo ili nikako obrazovani, često i nepismeni, koji su donijeli i svoje običaje, vjerovanja i priče koje su znali i sve je to zajedno, u različitim omjerima i intenzitetu, prodrlo u kanonske spise koje su čitali, komentirali, međusobno prepričavali, a i dalje prenosili puku. U tome kontekstu možemo objasniti strukture usmenoga pripovijedanja u njima, kojima je temeljna funkcija bila konverzacija, zabava, ali i usporednu težnju obrazovanih klerika koji su nastojali strože kontrolirati duhovnost. Ta su dva smjera - rigorozno čuvanje duhovnosti i otklon od kanona umetanjem zabavnih pa i smiješnih dijelova-usporedno supostojala: glagoljašku matricu pratimo sve do baroka i iz nje možemo iščitavati motive, teme i stil usmenog pripovijedanja. Cjelovite i samostalne tekstove predaja imamo tek od 19. st. sa sviješću kroz kolike su utjecaje i intervencije prošli tradiranjem: crkvene, pisane, književne, učene i zapisivačke. Kasniji pripovjedači legendarnih sadržaja dolazili su iz brojnih skupina nižih socijalnih slojeva, ali je dodir sa svijetom crkve ili samostana bio i ostao velik oslonac njihovih priča.

Ma koliko biblijske priče bile kanon, dugotrajno ih je pričanje preoblikovalo i prilagodilo vlastitim pripovjedačkim pravilima. Bilo bi ih pogrešno 
tražiti samo u povijesnim izvorima, u religijsko-crkvenoj literaturi, u egzemplima, prilikama ili u njihovim popularnim preradama ili prepričavanjima. One se pričaju "na terenu" i ovdje su prikazane one što su prikupljene i u autentičnim pripovjedačkim situacijama (iz Slavonije, Banije, s Cresa, Mljeta, okolice Dubrovnika). Pojedinačne tekstove nalazimo u antologijskim zbirkama priča iz Hrvatske.

Novi zavjet daje dovoljno pripovjedačkih mogućnosti za nadogradnju parabiblijskih tema. Podudarnost obaju zavjeta nalazimo u etiološkim (i kozmogonijskim) predajama o postanku biljaka, životinja ili tek nekih njihovih osobina. Poticaj brojnim legendarnim pričama nedvojbeno su bile legende o Djevici Mariji i apokrifne priče iz Isusova djetinjstva.

U temama što su usko naslonjene na biblijske priče žanrovski ipak dominiraju predaje jer one izrastaju iz ljudske znatiželje, a funkcija im je zabavna, komunikacijska, konverzacijska, ali i poučna. U apokrifnim temama ne odgovaraju samo na pitanje kako (je nešto nastalo), nego i zašto? I uvijek je u pozadini fabula, zabavna, jednostavna, najčešće jednoepizodna, koja to tumači i ilustrira slikama koje svojim konturama odgovaraju biblijskome događaju, ali mnogo više spoznajnom horizontu neuka čovjeka koji si emotivno, bliskim slikama tumači neshvatljivo. Oni se - poput apokrifa gdje je njihova ne samo tematska nego i strukturna te stilska veza - najizravnije obraćaju "duhovnosti i znatiželji [ne samo] srednjovjekovnog čovjeka, ne prešućujući ono što su službena konfesionalna doktrina i liturgijska knjiga ocijenile kao neprimjereno temi" (Hercigonja 2010: 52-54). I ovdje su najbrojniji tekstovi kozmogonijskih i etioloških predaja. Priče objašnjavaju stvaranje prvih ljudi, Adama i Eve, njihove djece, biljaka i životinja, prate starozavjetne priče u većem ili manjem broju tekstova, ali se te iste priče, modificirane, pričaju i uz rođenje i život Isusa Krista i time se, kao i u književnoj matrici, uspostavlja svojevrstan paralelizam između Staroga i Novoga zavjeta.

Josip je kao Marijin zaručnik bio odabran čudom: veliki je svećenik u jeruzalemski hram pozvao "sve mladiće i udovce, potomke Davidove" i "kazao kome štap procvate, postat će zaručnik Djevice Marije. Kao znak Božjeg odabranja, čudesno propupa Josipov štap, a nad njim zaleprša golubica Duha Svetoga" (Đurić 2007: 61). Čudesan izbor Josipa za Marijina zaručnika nije dio Novoga zavjeta. Štap je isto tako neodvojiv Mojsijev atribut i jasna je poveznica, kao što su znani paralelizmi između Mojsija i Isusa i u detaljima iz života i u djelima.

Slično su prepleteni tematski nizovi priča o pokolju prvorođenaca u Egiptu s Herodovim ubijanjem djece: židovska djeca spašena su u Egiptu 
jer su dovraci židovskih kuća s novorođenčadi bili obilježeni janjećom krvlju, a Isusa od Herodova progona skrivaju i spašavaju biljke i životinje koje su zbog toga posvećene pa do danas u pučkome imaginariju imaju posebna mjesta: ponad kutnih vrata gdje se rodio Isus samonikao je bršljan i kad su Židovi tražili Isusa, ostavljali su grančice bršljana na vratima kuća koje su pregledali. Na kući Isusova rođenja ugledali su bršljan, okrenuli se i otišli. "Od onda je lipo (od najdavnije davnine) postao običaj kititi kuće i vrata o Božiću bršljanom, jer je onaj bršljan sačuvo Isusa, da ga nijesu Žudije pogubili, kad je sam u tini čas niko i pokazo se" (Zovko 1901: 302-303). Inače je običaj da se o Božiću kuća kiti bršljanom jer se vjeruje da čuva od vještica, što samo pokazuje koliko je duboko i neraskidivo prepleteno pogansko i kršćansko. Istovjetna je priča i o pauku koji je u jedan tren spleo mrežu na ulazu u kuću gdje je bio Isus pa su vojnici povjerovali da tu odavno nitko nije bio. Paukova mreža u osnovi ima križ pa se zato kroz križ ne smije ubiti pauka (Dänhardt 1983:17).

Novi je zavjet velik izvor priča i na Zapadu. Lakune u novozavjetnoj priči (Isusovo djetinjstvo, Marijin život, kasnija sudbina apostola) ispunjavale su se rado apokrifnim usmenim pričama, vrlo često sa začuđujućom lakoćom mijenjanja prvotne priče i uloge pojedinih biblijskih osoba. Neke su se od tih priča odvojile od biblijskih priča te potpuno samostalno zaživjele i prenosile se (priče o sv. Petru). Ma koliko bile kanon, dugotrajno ih je pričanje preoblikovalo i prilagodilo vlastitim pripovjedačkim pravilima. $\mathrm{Ne}$ nalaze se samo u književnopovijesnim izvorima, u religijsko-crkvenoj literaturi, u egzemplima, prilikama ili u njihovim popularnim preradama ili prepričavanjima. One se još uvijek pričaju "na terenu" i ovdje su, uz tekstove iz ZNŽO-a prikazane i one što su prikupljene u autentičnim pripovjedačkim situacijama (kao što sam navela, iz Slavonije, Banije, s Cresa, Mljeta, okolice Dubrovnika). Nema objavljene tematske zbirke, premda pojedinačne tekstove nalazimo u antologijskim zbirkama iz Hrvatske. Ne znam zašto, ali pretpostavljam da je to i zbog njihova otklona od kanona, priklanjanja apokrifnom, katkad frivolnom i erotskom (primjerice u priči o Adamu i Evi, Eva je predstavljena kao seksualno nezasitna žena pa otuda toliko djece, tj. ljudskoga roda - Bogišić 1953: 351), ${ }^{5}$ ali najčešće smiješnom i naivnom.

5 Velik je broj (u Zbornicima za narodni život i običaje, ali i u terenskim zapisima do kraja 20. st.) gotovo invarijantnih lokalno udomaćenih tekstova o postanku ljudi i mitskoga svijeta, koji zvuče kao nastavak navedene fabule: pripovijeda se da je Bog posjetio Adama i Evu da vidi kako im je na svijetu i molio da mu pokažu djecu. Pokazali su mu šestero od dvanaestero jer su 
One otvoreno i smjelo otkrivaju tabue, duhovito govore o svetim stvarima, svaki put poštujući tradicijski dodijeljene uloge blage majke i zaštitnice Majci Božjoj, pravičnoga suca Isusu i slikovite maštovite raznorodne prikaze njegova najčešćeg pratitelja Petra koji obilato predstavlja sve ljudske mane i rijetke vrline.

Ilustrirat ću izneseno usmenoknjiževnim tekstovima koji nisu zamišljeni kao cjelovit sustavan pregled, nego kao kroki, vinjeta, tek lepršav uvid u to usmenoknjiževno gradivo. Govore o navještenju, Isusovu rođenju, bijegu Svete obitelji te, posljedično, o čudima oko Božića.

U egzemplu što ga je objavio Strohal rimski je Oktavijan ugledao čudnu svjetlost u noći Isusova rođenja:

"Izajde vanka i pogleda u nebo i nije mogao od svjetlosti gledati i pade s obrazom dolje od straha. Potom se uzdignu i vidi tri sunca i jedno sunce, koje bijaše u sredini, bijaše najsvjetlije. I poče car od milja plakati i suze proljevati, jer je vidio u središtu jednoga sunca jednu plemenitu kraljicu i ditića daržeći. Ditić križ daržaše u rukah svojih." Počeo ih je kaditi u nebesima. Dokaz tomu je, govori dalje egzempl, crkva koju je na mjestu navještenja dao izgraditi Oktavijan (Strohal 1918: 107).

Taj tip priče pripada crkvenim prilikama iz glagoljaške hrvatske književnosti. Slično objašnjenje za novu zvijezdu na nebeskome svodu nalazimo i u Lovretićevoj monografiji o Otoku, gdje spominje zvijezdu priodnjicu koja je bila znamen i putokaz Isusovu rođenju i po njoj se ljudi ravnaju ako će kamo na dalek put (Lovretić 1902: 113).

Isusovo rođenje opjevano je i u usmenim pjesmama, molitvicama. $\mathrm{U}$ njima je u prvome planu kršćanska priča o Isusovu rođenju u staji, ispjevana u inačicama što su tek u detaljima lokalno kontekstualizirane. Najčešće je to prisna pjesma o majci koja nastoji utopliti, skriti i nahraniti tek rođeno djetešce (više u Marks 2011). Prozni tekstovi slijede taj model. Uz Isusa su se našle i životinje i predaje govore upravo o tome: "Konj je postao od Isusova živinčeta (magareta): čim je došlo nadomak Isusu, odmah se u konja pretvorilo" (Zovko 1898: 141). Konj je s tek rođenog Isusa stalno skidao peću da bi jeo i tako ga otkrivao, a vo je na nj navlačio slamu da ga utopli i stoga je konj proklet da se nikad ne najede, a vo se najede brzo (Petković

se sramili tako velikoga broja. Bog tada reče: Koliko vidljivih toliko i nevidljivih - i vjeruje se da su tada nastala sva nevidljiva mitska bića (vile, dobrice, vilenici, vještice i sl., npr. Lovretić 1902: 121-122). 
1912: 152). Priča se da u bukvu nikad neće grom jer je od bukova drva bila Isusova zipka, a u jelu grom rado udara jer je "jelva šumela nad štalicun, kad je mali Isus spal, pak da ga j’ probudila” (Jardas 1957: 309). Isusa od Herodova progona skrivaju i spašavaju biljke i životinje koje su zbog toga posvećene pa do danas u pučkome imaginariju imaju posebna mjesta, primjerice već spomenuti bršljan.

Proklinjanje nekih biljaka motivski je isto tako sukladno pjesmama te kozmogonijskim predajama i legendarnim pričama koje tematiziraju bijeg Svete obitelji u Egipat. Osnovni im je siže uvijek isti: Židovi žele Mariji oduzeti i ubiti Isusa, a ona bježi i skriva dijete. Priča nije potvrđena u evanđelju, pripada samo usmenoj tradiciji na širemu slavenskom prostoru. Među biljkama koje su proklete u pjesmama javljaju se sviba (vrba), gloginja, gložina, topola i topolje te jablan. Utočište pružaju brezica, rakita, vrbica, smreka pa ih Gospa blagoslivlje (Đorđević 1939: 190-192). ${ }^{6}$ Iz Marijine kazne ili nagrade potječu i traju njihove osobine do danas: Dok je Herod progonio Svetu obitelj

ide za jnimi kokoš i prasica; prasica zote, da zarova trag, da ne bi Rodešovi znali traga za jnemi, a kokoš je rezgrebala straga, da se naj vidi. Ogleda se Marija nazaj i vidi dobre i zle dele, pak reče prasici: "Ti boš leže zlegla devet komadov praščičov, neg kokoš jene jajce" (Kotarski 1918: 44).

Išli su dalje: list na topoli je trepetao i Marija je prokle da navijek trepeće (Kotarski 1918: 44; Lovretić 1902: 195-196), kupina joj se zadjenula o plašt, Marija se uplašila i molila da je pusti i da će navijek biti zelena (Kotarski 1918: 44). Skriva je vrba jer svije svoje grane (Franković 1994: 132). ${ }^{7}$ Bučjak (vučjak) je toliko šumio kad se Marija skrila u polju da ga je proklela: "Kako je žuko srce moje, tako bilo žuko sjeme tvoje!" pa tom da je bučjak žuk (Zorić 1896: 247).

6 Majka Božja je dosljedna u svojim pohvalama i kaznama i u drugim situacijama, katkad i tašta, pa ima primjera gdje kune drveće: jasiku zato što ne miruje dok u crkvi pjevaju sv. Petar i Nikola, a otpjevaju im sestrica Anđelija i Marija; svibu i gloginju jer joj se ne pokloniše dok joj se svako drvo klanja; kune i tri neimenovane gore što joj se ne pokloniše (više u Šetka 1969: 315).

7 Vrba se svije i nad Blaženom Djevicom Marijom pod križem i tješi je: "Kad su gospodina našega Isukrsta opaki Žudije razapeli, tada njegova majka, Blažena Djevica Marija, side pod žalosno drvo i gorko stane za svojim milim sinom žaliti. Zato žalosno drvo spušta k zemlji grane, kao da i ono tuguje i plače" (Petković 1907: 153-154). 
Predaje o bijegu Svete obitelji u Egipat zauvijek određuju i izgled ili osobine životinja koje su se našle tamo: Djevica Marija je jašila na mazgi. Ali dok je ona jašila, mazga je jela smeće i zato se mazga ne može okotiti. "Onda se ona opet uzjašila na tovara. I tovar ju je nosio i zato je na njemu križ” (Bonifačić Rožin 1965: 115).

Kad su Mariju, malog Isusa i Jožefa Žudije zaganjale, onda je išla po strnjaku Marija. Ja znam još i pokazat, iščupala bi ti i bi ti u ruke dala tu travu na kojoj se slopnice videju kako je Marija sise davala malom Isusu i mleko njoj padalo na travu.

A kad su išli kroz rit, onda magarac je zagrizo u trsku i sada se vide magareći zubovi, a na žitu Isusova slika.

A kad je bežala Marija š njim, onda je i pod vrbicu ošla pa rekla: - Vrbice, sestrice, pokri mene i mojega sinka, nek me ne ufatiju Žudije!

I vrbica spustila je grane i pokrila Mariju i malog Isusa, i Žudije nisu nje našli.

(Franković 1994: 132)

Kršćanski i apokrifni motivi s vremenom i tradiranjem pojedinih sižea prerastaju okvir priče o bijegu i umetanjem motiva i likova mitskih predaja slabe biblijsku priču, ali pojačavaju fikcijski dio, tako omiljen i pripovjedačima i publici: primjerice, na svojem je bijegu Sveta obitelj vidjela da vile ujutro siju pšenicu, a žanju je uvečer. Kad su do vila stigli rimski vojnici, upitali su ih kad su vidjeli obitelj u bijegu. Na odgovor: kad smo sijale pšenicu, vojnici su se okrenuli i otišli (Bonifačić Rožin 1959: 102). Taj se motiv češće veže samo uz seljake koji su sijali pšenicu i ujedno tematizira jedno od čuda Majke Božje:

Dođu - jedan čovik ore, sije žito. A Marija sidne s diteton, š njin da sije žito. Kaže: - Čovče, daj i meni da posijen to žita.

Na. Ali - kaže - biži, vojska je za vami, pa će te oni, mogu vas pogubit.

A ona uzela žito i sije. Kako god ona sije, tako žito raste, veće je nego da se ženje. Ona kroz to žito i Jozip i ditića Isusa nosi i uteče nizbrdo u polje. Intra jedna gora što se savila, nizbrdo oklopila, potom Marija i Jozip ditića unesu poda tu goru. Oni došli tuta, oni Irudovi, ta Irud i ti što će zaklat Isusa.

Kaže: - Ajde, šta misliš - kaže oni - kuda je ovuda ta žena?

- Jest prošla - kaže - jedna ženska, jedan čovik i jedno dite kad san ja sija šenicu.

Oni govoru: - Kako to kad si sija šenicu? Da di su oni sada?

A šenica velika.

(Bošković-Stulli 1993: 239-240) 
Time priča nije gotova: Sveta obitelj u olujnoj noći pronalazi utočište pod krovom jednoga od Herodovih progonitelja koji ima gubavo dijete. Marija dopušta majci da okupa svoje bolesno dijete u vodi u kojoj je okupala Isusa i time se dijete izliječi: "Ostade joj zdravo ko cekin to dite. Otolen Blažena Divica Marija i Jozip odu i krenu ća. Kad su Isusa propinjali, i njega su propeli, toga njezina sina, s live strane Gospodina, kad su ga propeli na križ." (isto).

Ni tu nije kraj; naime upravo je to dijete bio onaj razbojnik koji je propet isti dan kad i Isus (Bošković-Stulli 1993: 239-240; Franković 2011: 68). Kraća inačica te predaje zapisana je među Hrvatima u Gradišću bez dodatka o kupanju i zajedničkom raspeću (Bošković-Stulli 1977: 424-425).

Božić je među najvećim kršćanskim blagdanima koji uvijek iznova evocira Isusovo rođenje i sve priče koje su se oko toga nataložile. To je istodobno i jedan od rijetkih blagdana u kojemu se ravnopravno miješaju pretkršćanski i kršćanski običaji, vjerovanja, predaje i pjesme. Predaje vezane uz Božić određene su vremenom u kojem se odvijaju te novozavjetnom pričom koju dijeli cijeli kršćanski svijet. No uvijek su čvrsto utisnute u lokalni pripovjedački prostor pa su nerijetko kazivane kao memorati, dakle događaji koji su se dogodili nekomu poznatomu i u svojoj stilizaciji pokazuju velik stupanj bliskosti i zbiljnosti opisanoga događaja. Ta se usidrenost u zajednicu prepoznaje u detaljima koji čitatelja/slušatelja, dakle nekoga sa strane, izravno uvode u događaj i s ostalima ga uranjaju u priču.

Tako se u uvodu u Božićna čuda u Kastavštini prvo pomno opisuju običaji, jela i pića, a potom slijedi priča uz Viliju božju: jedan priča, drugi slušaju. Očekivani uobičajeni slijed događaja: pjesma, jelo, piće, priča... ne dopušta uzmak ni pitanja o mogućoj fikcijskoj naraciji. Tu smo kao publika, $\mathrm{s}$ pripovjedačima i slušateljima za blagdanskim stolom i sudjelujemo $\mathrm{u}$ svemu:

Kad na Viliju božju fine koledvat, piju vino, jedu pečen kostanj i ulenjaki, a potom pripovijedanje. [...] Ki dobro zna, povda ganki i storije od stvari, ke su se zgodile i ke se moru zgoditi na Viliju božju. Jedan povda, a drugi poslušaju (Jardas 1957: 27-28).

To je jedno od stilskih sredstava predaje kojima ona, istaknutim detaljima, gotovo olfaktorno, jamči vjerodostojnost kazivanoga i ne dopušta uzmak. Pojačano je to ovdje izvrsnim opisom da priča onaj tko dobro zna, što osnažuje ulogu pripovjedača, ali se kazuje i da se govore stvari koje su se dogodile i mogu se dogoditi na Badnjak; time se doba Božića, Badnjaka, 
budne noći, noći kad svi bdiju, izdvaja iz ostalog vremenskog protoka. To je noć kad se otvara nebo, kad našim mrtvima serviramo tanjur za jelo, razgovaramo sa životinjama, kad se ostvaruju želje, pretkazuje godina, život i smrt, kad se otkrivaju vještice na ponoćnoj misi (Lovretić 1902: 122; Lang 1914: 122; Mikac 1907/12: 298-301). Mističnost i svetost, običajno i izvanredno, zatravljenost i strah na istoj su razini doživljajnoga. Neupitno je moguće sve, i zato se taj trenutak ne smije propustiti ili zlorabiti. Greška se kažnjava: žena je dobila kravlju glavu (Jardas 1957: 27-28), muškarac greškom čekiće jer nije znao kazati riječ cekine (Bošković-Stulli 1967: 374).

Likovi iz mitskih predaja, ponajprije vile, mogu biti aktivni sudionici i u čudesnom kršćanskom događaju, premda ipak rubno. Ponašaju se shodno svojem djelovanju u najširem motivskom krugu predaja s vilama kao glavnim likovima: pomažu ili odmažu čovjeku. Sve što se događa u toj noći potpuno je jasno, oštro i nepopravljivo: Vile su na Badnji dan "balale u Vakete na taraci kod Nike Sturice, a vilenik je udaro u vijolin". Neka ih je djevojčica pohvalila. "A vila jom odgovorila: Nama dobro, a tebi zlo. I subito su razmetli bal er hi je ona omela. I došla je na dno ulice, i sva se zgrčila u balotu. I donijeli su je sa dno ulice doma i odma je umrla. Svrha" (Bogišić 1953: 94). To je i noć kad mitska bića najsnažnije prodiru u ljudski svijet: u predaji, gotovo egzemplu o čovjeku koji je u Samoboru išao loviti u božićnoj noći odzvanja srednjovjekovna tema o jagarima, noćnim lovcima, nesmirenim umrlim dušama lovaca koji noću love po šumama, ovdje pretvoreni u vukove. Oni su ga pretvorili na sedam godina u vuka, nakon čega su ga vratili u ljudski lik uz opomenu da se u božićnoj noći ne smije loviti (Lang 1914: 217-218).

Sve te priče, zajedno s brojnima ostalima koje bismo mogli uvrstiti u neku hrvatsku Bibliju pauperum dojmljiv su dokument o tome kako je 2000 godina kršćanstva i kršćanskoga nauka shvatio, interpretirao, sačuvao i prenosio narod, kako je strog, egzaktan nauk proširen i dopunjen fantastičnim dijelovima iz mitskih usmenih predaja. Te predaje uvijek pogađaju najosjetljiviju ljudsku točku. One izazivaju i golicaju ponajprije svojim finim tkanjem smiješnoga i ozbiljnoga, sakralnoga i profanoga. 


\section{LITERATURA}

Biljan, Mijo. 1907. Manji prinosi. Narodne gatke. (Budak u Dalmaciji). “Zbornik za narodni život i običaje”, 12: 151-156.

Bošković-Stulli, Maja. 1963. Narodne pripovijetke. Priredila. Pet stoljeća hrvatske književnosti 26. Zagreb: Matica hrvatska-Zora.

Bošković-Stulli, Maja.1967. Narodne pripovijetke i predaje Sinjske krajine. "Narodna umjetnost" 6 i 7: 329-372.

Bošković-Stulli, Maja. 1987. Usmena književnost. U: "Povijest hrvatske književnosti u sedam knjiga" 1. Usmena i pučka književnost. Zagreb: Liber-Mladost, 7-353, 641-651.

Bošković-Stulli, Maja. 1993. Žito posred mora. Usmene priče iz Dalmacije. Odabrala i uredila. Split: Splitski književni krug.

Bošković-Stulli, Maja. 1997. Usmene pripovijetke i predaje. Zagreb: Matica hrvatska [Stoljeća hrvatske književnosti].

Curtius, Ernst R. 1971. Evropska književnost i latinsko srednjovjekovlje. Zagreb: Matica hrvatska.

Dähnhardt, Oskar. 1983. Natursagen. Eine Sammlung naturdeutenden Sagen, Märchen, Fabeln und Legenden. Sv. II: Sagen zum Neuen Testament. Hildesheim, Zürich, New York: Georg Olms Verlag [reprint izdanja iz 1909].

Dürrigl, Marija-Ana. 2013. Hrvatska srednjovjekovna proza II. Apokrifi, vizije, prenja, Marijini mirakuli. Zagreb: Matica hrvatska [Stoljeća hrvatske književnosti].

Đorđević, Tihomir, R. 1939. Beleške o našoj narodnoj poeziji. "Prilozi proučavanju narodne poezije" VI. Beograd.

Đurić, Tomislav. 2007. Legende puka hrvatskoga 2. Samobor: Meridijani.

Ecker, Hans-Peter. 1996. Legende. "Enzyklopädie des Märchens”, VIII, 2-3: 855-864. Berlin, New York: Walter de Gruyter.

Fališevac, Dunja. 1980. Hrvatska srednjovjekovna proza. Zagreb: Hrvatsko filološko društvo/ Znanstvena biblioteka.

Franković, Đuro. 1994. Pučka Biblija. “Etnografija Hrvata u Mađarskoj”, 1994: 127-137.

Frenschkowski, Marco. 2005. Schöpfung. "Enzyklopädie des Märchens”, XII, 1: 170-180.

Gunkel, Hermann. 1901. The legends of Genesis. Chicago: The open Court Publishing Co.

Hercigonja, Eduard. 2010. Apokrifi. Hrvatska književna enciklopedija, 1 (A-Gi). Zagreb: Leksikografski zavod Miroslav Krleža, 52-54.

Jardas, Ivo. 1957. Kastavština. Građa o narodnom životu i običajima u kastavskom govoru. "Zbornik za narodni život i običaje”, 39.

Kekez, Josip. 1989. Leukorn i djevojka bez grijeha. Slike i prilike pripovijedane u Hrvata. Zagreb : Znanstvena biblioteka Hrvatskoga filološkog društva.

Krmpotić, Ivan. 1913. Vjerovanja. (Osička općina u Lici). “Zbornik za narodni život i običaje", 18/1: 190-191.

Lang, Milan. 1914. Samobor. "Zbornik za narodni život i običaje”, 19: 39-152.

Lovretić, Josip. 1990. Otok. Narodni život i običaji. "Zbornik za narodni život i običaje”, 7: 57-206. 
Marks, Ljiljana. 2011. Križi lete po nebu. Molitvice iz Dubrovačkoga primorja. (ur.) Dubrovnik: Matica hrvatska.

Mikac, Franjo. 1907. Manji prinosi. Božični običaji i vjerovanja. (Sv. Martin u Međumurju). "Zbornik za narodni život i običaje”, 12/2: 298-301.

Petković, Grgo. 1912. Manji prinosi. Narodne gatke (Budak u Dalmaciji). “Zbornik za narodni život i običaje", 12/1: 151-156; 303-304.

Radić, dr. Antun. 1929. Osnova za sabiranje i proučavanje građe o narodnom životu, drugo izdanje. Zagreb: JAZU.

Strohal, Rudolf. 1916. Zbirka starih hrvatskih crkvenih pjesama. Sabrao iz starih hrv. glagol. rukopisa od 14.-18. vijeka. Zagreb.

Strohal, Rudolf. 1918. Prilike iz stare hrvatske glagoljske knjige. "Zbornik za narodni život i običaje" 23: 64-124.

Šetka, fra Jeronim. 1969. Majka Božja u hrvatskim narodnim pjesmama. "Kačić. Zbornik Franj. provincije presvetog otkupitelja", 2: 301-392.

Zorić, Mate. 1896. Narodna vjerovanja s bajanjem. Kotari. "Zbornik za narodni život i običaje", 1: 259-260.

\section{RUKOPISI}

Bogišić, Valtazar (Baldo). 1953. Narodne pripovijetke $i$ dr. iz Bogišićeve biblioteke $u$ Cavtatu: rukopisni zapisi Marije Pohl-Bogišić, V. Bogišića, I. Miljana i dr. (god. 1855.-1891.), IEF rkp. 189. [IEF rkp = Institut za etnologiju i folkloristiku, rukopis] Bonifačić Rožin, Nikola. 1959. Folklorna građa Dvora i okolice. IEF rkp. 329.

Bonifačić Rožin, Nikola. 1965. Folklorna građa s otoka Mljeta. IEF rkp. 749.

Franković, Đuro. 2011. Pučka Biblija, rukopis

Marks, Ljiljana. 1974. Narodne pripovijetke, predaje i pjesme iz Šaptinovaca (Slavonija), 1, IEF rkp 930.

\section{SUMMARY \\ WHEN THE HEAVENS OPEN UP: BIBLICAL AND PSEUDO-BIBLICAL STORIES IN ORAL TRADITION}

In Croatian medieval literature apocrypha are not a homogenous generic category and may rather be seen as a suprageneric group of texts which tell stories about biblical men and women and their deeds which are not portrayed in the biblical canon. Even though apocrypha are popular fictional works, the stories are always presented as nonfictional, establishing a firm connection with the Bible - its contents, the Christian doctrine and its ethical message. Since they were written to be read out loud, their open structure 
allows for the author's individual style, borrowing and combining motives, a free interpretation of the narrative sequence, narrative rhythm which draws on oral literature, and affects the recipients' feelings by moving them emotionally while also entertaining them. The corpus of oral stories and legends (in both older and newer transcripts) demonstrates what happens when a "sacred text" completes its transition from a written to an oral form: texts reshape, the unimaginable is explained in familiar terms, the divine is supplemented with that which is human. But what this process of folklorization creates is a more or less a successful mixture of serious and comical, a fun, relaxing Bible which instructs but also entertains. While the morality of stories subsides, fantastic and fairytale elements multiply, original biblical stories are supplemented with apocrypha which introduce elements of legends, anecdotes and fairytales. Most of these texts belong to the genre of cosmogonical and etiological legends which establishes the firmest link between the past and the present; they speak the narrator's language, they give names to things in the world, thus explaining it and adding to it additional meaning. By interpreting selected texts about the Genesis, the origin of man, the annunciation and the birth of Christ, the Holy Family's flight into Egypt and other Christmas miracles, the paper demonstrates that the narrative corpus which thus forms is not a random medley or an intricate bundle of heterogeneous texts of different origin and age. All these stories, together with many other which could be assembled in a provisory Croatian Bible pauperum, represents an impressive document on how the Croatian people understood, interpreted, preserved and passed on a two-thousand-year old history of the Christian doctrine.

Keywords: The Bible, pseudo-biblical stories, legends, apocrypha, oral literature, Croatia 